\title{
Assessment of Soil-Water Infiltration Dynamics of Waste Oil Polluted Terrestrial Habitat Under Macrophytic Remediation: A Window for Automobile Workshops
}

\author{
Nsirim, Lucky Edwin-Wosu ${ }^{1 *} \quad$ Ani, Nkang ${ }^{2}$ \\ 1.Department of Plant Science and Biotechnology, Faculty of Science, University of Port Harcourt, \\ Choba, PMB 5323, Port Harcourt. \\ 2.Department of Botany, University of Calabar, P.M.B 1115, Calabar, Nigeria
}

\begin{abstract}
Automobile workshops are the hub of waste oil sources among other sources of pollution with it attendance consequence of physico-edaphic alterations of the terrestrial soil habitat. This research was aimed at reevaluating the demonstrated potential of three hydrocarbon tolerant leguminous species; in view of their application in automobile workshop surroundings. Field and laboratory analysis of the physico-edaphic parameters were carried out using universally acceptable standard methods. Result has recorded enhanced infiltration rate by phytotechnology among Peltophorum pterocarpium (Pp), Leucaena leucocephala (L1) and Crotolaria retusa $(\mathrm{Cr})$ waste oil soils in the order $P p<C l<L l$; in which $P$. pterocarpum has increased infiltration at lesser time rate of 1.07 $\pm 0.31,1.51 \pm 0.02,2.48 \pm 0.35$ and $3.13 \pm 1.45$ across levels of treatment with significant difference $(p<0.05)$. This was correspondingly in direct relationship with the significantly enhanced particle size (87.73\%) of sand, and $2.61 \mathrm{~g} / \mathrm{cm}^{3}$ particle density, reduced bulk density $\left(0.83 \mathrm{~g} / \mathrm{cm}^{3}\right), 68 \%$ porosity increase and reduced organic matter content of $2.65 \%$, total hydrocarbon content reduction of $1.8 \mathrm{mg} / \mathrm{g}$, high efficiency of $55 \%$ hydrocarbon removal, 34.40 bioaccumulation quotient and $24.63 \%$ reduction in crusting hazard of sealing recorded. Conclusively, $P$. pterocarpum can be proposed for automobile workshops as a proactive measure and containment absorbent among other hydrocarbon restoration approach against envisaged waste oil discharge.
\end{abstract}

Keywords: Crusting hazard, total hydrocarbon, root formation, bioaccumulation quotient and particle size.

DOI: $10.7176 / \mathrm{JEES} / 9-3-07$

Publication date:March $31^{\text {st }} 2019$

\section{Introduction}

Environmental pollution by hydrocarbon and its products especially with the spent lubricating oil (SLO) or waste engine oil (WEO) has become the most prevalent and major source of diffuse or non-point source of oil pollution to the environment because of its strong toxic properties (Rudko and Rybczynski, 2010; Anna et al., 2015). Thus with the prevailing indiscriminate incidents in the environment has indicated wider pollution spread than crude oil pollution (Atuanya, 1987). This creates a serious monitoring and control challenge as mechanic workshops and mechanic villages spring up without proper planning and policy framework for management of waste oil and protection of the environment. Waste engine oil (WEO) is an organic by product of mineral-based crankcase and lubricating oil subjected to high temperature, high mechanical strain (ATSDR, 1997). A fluid with dark brown to black colour based on varying composite constituent. It is a common and toxic environmental contaminant not naturally found in the environment (Dominguez-Rosado and Pitchel, 2004). It contains a mixture of different chemicals including low to high molecular weight (C) compounds (mono and multi-grade crankcase oils from petrol and diesel engines), lubricative additives (gear oils and transmission fluids), and decomposition products with significant levels of hydrocarbons, chlorinated biphenyls, chlorodibenzofurans and other properties present in all petroleum products and heavy metals which have been found to be harmful to the soil biotic and abiotic environmental factors (Dauda and Obi, 2000; Wang et al., 2000; Duffus, 2002; Adedokun and Ataga, 2007; Adu et al., 2015). It is usually obtained after servicing and greasing of motor parts and subsequent drainage from engines, changing of lubricating oil, and replacement of worn-out parts and generators by auto-repairers (Anoliefo and Vwioko, 2001; Ajayi, 2005; Sharifi et al., 2007).

Service stations in most parts of developing nations such as Nigeria find it difficult to properly dispose of the SLO hence large volume is indiscriminately disposed on open plots of land, sewage, farm lands and drainage ditches (Odjegba and Sadiqi, 2002) and the government has not put in place a functional and sustained mechanism to monitor and/or control the discharge of this oil from auto-repair workshops, because it has proved very difficult to regulate their activities by virtue of their small size. This result in the disposal of spent lubricating oil on the soil and has contributed markedly to the problems of soil pollution as the oil gets to the environment due to discharge by auto-repairers (Odjegba and Sadiq, 2002) and from the exhaust system and engine leaks (Anoliefo and Edegai, 2000; Osubor and Anoliefo, 2003).

Soil is a primary and natural sink for a myriad of products and chemicals used in modern society. Once these waste materials enter the soil they become part of the biogeochemical cycle that affects all forms of life. Toxic 
pollution of terrestrial environment could militate the natural potential for ecosystem supporting and provisioning services of soil habitat. Several studies have documented the multiplier implication of hydrocarbon and its products on the soil ecosystem. The saturation of soil by fluids characterized by physico-chemical properties that differ from water has been found to have a deteriorating effect on its mechanical and filtration parameters, plasticity, swelling and other properties (Baranaski and Wytrzymalosaca, 2000; Herzig, 2001; Izdebska-Mucha, 2005; Mashalah et al., 2007). In general, oil contamination reduces the permeability, strength and Atterberg limits by increasing oil contamination in clay soil, (Mashalah et al., 2007; Ashraf, 2011). Marked changes in the physical, chemical and biological properties of soils contaminated with lubricant oil have been documented in light of air and water displacement leading to anaerobic condition (Atlas, 1977); microbiological properties (Ekundayo et al., (1989), increased bulk density, decreased water holding capacity and aeration propensity, decreased porosity and hydraulic conductivity (Udom et al., 2008; Kayode, et al., 2009; Inwite and Alu, 2015; Edwin-Wosu and Nkang 2017a).

Oxidation of lubricating oil hydrocarbons at the point of application is accompanied by release of free radicals that transform to peroxides, subsequent condensation and polymerization of which produces acids, such as nephtenic acids, etc (Evdokimov and Fooks, 1989). However, this is dependent on the local environmental conditions and on the kind of soil constituents present in the soil-water system. Due to the difference in the composition of the different petroleum products, the environment is affected in different manners in light of its physico-chemical and mechanical properties at different rate (Wyszkowski and Ziolkowska, 2008).

The foregoing premise invariably justify the need for understanding the dynamics of infiltration rate vis-àvis some selected edaphic properties (soil texture, structure, bulk density, particle density, porosity, and organic matter) under phytoremediation of waste oil polluted soil. Since conventional remediation processes are limited in application, possibly due to sophistication and high cost implication phytoremediation is becoming an increasing important method of waste treatment. Phytoremediation, a subcategory of phytotechnology, uses plants either solely or / and synergistically with microbes to absorb and degrade organic and inorganic pollutants from environmental media (soil, air or water) (Shanon, 2017). This technology had worked for the degradation of contaminants in soil thus making the soil useful for other purposes. It is expected that further studies on this method of remediation will expose us to greatly appreciate nature's gift of cleansing our environment for mankind and also be a window of exploit for the automobile repairers using Peltophorum pterocarpium, Leucaena leucocephala and Crotolaria retusa) leguminous species of the Fabaceae family .

\section{Materials and Methods}

The study was carried out in two phases involving: field work and laboratory analyses.

\subsection{Field work:}

\subsubsection{Sources of materials}

Microplot replicates of $20 \mathrm{~kg}$ top loam soil within a $0-15 \mathrm{~cm}$ depth after the Stewarte et al. (1974) and Song et al. (1990) methods were collected in bulk from a fallowed land of the Faculty of Agriculture, University of Calabar, Cross River State. The seeds of test plants, Peltophorum pterocarpum (DC.) Heyne, Leucaena leucocephala (Lam) De Wit. and Crotolaria retusa Linn were obtained from the wild. The waste oil was obtained from an automobile workshop in Port Harcourt, Rivers State, Nigeria.

\subsubsection{Experimental design and pollution of the study micro-sites with waste oil}

A double split "nested design" plot according to Akindele (1996) was adopted in which a nested analysis of variance procedures (PROC. ANOVA) (SAS, 2002) was carried out on the infiltration data vis-à-vis physicoedaphic parameter of the waste oil polluted sites. The pollutant was surface simulated using a measuring cylinder in four levels of mill concentration (V/W \%) doses of $0 \%, 75(0.4 \%), 150(0.8 \%)$ and $300(1.5 \%)$ per $1,809 \mathrm{~cm}^{2}$ surface area. Three (3) species of the test plants for the phyto-treatments were used in the remediation of 3 different simulated levels of waste oil polluted site that were in replicates of five. Differences in post-pollution soil, postphytoapplication species performance and soil were tested using the parameter replicates by treatment interaction and treatment by levels interaction as the error terms.

\subsubsection{Post-pollution habitat reclamation treatment using the phytometers}

Habitat reclamation treatment commenced 7 days after the pollution of the habitats. Each of the three different levels of polluted replicates and the control replicates were subjected to post-pollution habitat reclamation using the three species (P. pterocarpum, L. leucocephala and C retusa) of Fabaceae plant family. Healthy 14 days old seedlings of the three species from the nursery were transplanted into the control and polluted soils in the microsites. The pre- and post-pollution and post phytoapplication growth performance of these seedlings were monitored for a period of ten (10) months and used as a measure of their level of tolerance in the polluted environment in relation to comparative analysis of the biota root formation, total hydrocarbon and organic matter content of the species. 


\subsection{Laboratory analyses:}

The baseline analyses of pollutant and pre-pollution soil was carried out. Post-pollution and post-phytoapplication recuperation of the polluted soil under the seedling was assessed by means of comparative analysis of the biotic and physico-edaphic parameters of the polluted soil using classical methods;

\subsubsection{Drying of soil samples}

The soil was air dried at room temperature not exceeding $25^{\circ} \mathrm{C}$ and $70 \%$ relative humidity by spreading on plastic trays $50 \times 60 \mathrm{~cm}, 25 \mathrm{~cm}$ deep. The soil was stirred occasionally to expose the fresh sub-surface moist layer.

\subsubsection{Grinding and sieving}

The soil was set for further treatment after air drying. Stones and pieces of macro-organic matter were removed. The remainder of the sample was crushed and sieved. Large lumps were broken up by hand. The soil was ground by rolling gently with an inert roller as to bring it to a relatively homogenous state. The soil was screened through a 2-mm sieve after grinding to give what is commonly referred to as the $2 \mathrm{~mm}$ fine earth. This was used for the analysis of soil structure, texture, total hydrocarbon and organic matter content.

\subsubsection{Pollutant characterization}

The waste oil used for the study was characterized using the ASTM procedures for the following properties: specific gravity, density, $\mathrm{pH}$, kinematic viscosity, and base water sediment and result given in Table 6 .

\subsubsection{Soil structure}

The ASTM (1961) and Bouyocous (1962) methods of particle size analysis for soil structure and textural analysis for various combination of sand, silt and clay using the Textural triangle model extrapolation (Harry and Nyle, 1962) was adapted.

\subsubsection{Bulk density (BD)}

Bulk density was determined by the core method of Black and Hartge (1986) using a core sample with a volume of $205 \mathrm{~cm}^{3}$ and designated formula.

\subsubsection{Particle density (PD)}

The Gradwell (1955) as modified in ASTM (1958) was adopted for particle density analyses using the Pycnometer gravity bottle of $50 \mathrm{~cm}^{3}$ capacity and designated formula.

\subsubsection{Porosity}

Porosity by percentage determination of total pore spaces was extrapolation from bulk and particle density analyses using the formula designate:

$$
\% \varnothing=(1-\underline{B D}) \times 100
$$

PD

Where $\varnothing=$ porosity

$$
\begin{aligned}
& \mathrm{BD}=\text { bulk density } \\
& \mathrm{PD}=\text { particle density }
\end{aligned}
$$

\subsubsection{Crusting hazard}

The Crusting hazard of hydrocarbon Risk of sealing $(R)$ was estimated using the Vander Watt and Claassen's (1990) method as: \%R = $\underline{\text { Organic matter x } 100}$

\subsubsection{Total hydrocarbon}

$$
\text { (Clay + Silt) }
$$

Total hydrocarbon (THC) content was analysed using the American Petroleum Institute (API) (1980) method, through which the content was estimated by reference to a calibration curve using toluene as standard.

\subsubsection{Organic matter}

Organic matter content was extrapolated from Organic Carbon following Walkley and Black (1934) method as modified in Nelson and Sommers (1982), in which a complete oxidation of aqueous potassium dichromate $\left(\mathrm{K}_{2} \mathrm{Cr}_{2} \mathrm{O}_{7}\right)$ mixed with sulphuric acid $\left(\mathrm{H}_{2} \mathrm{SO}_{4}\right)$ and the residual $\mathrm{K}_{2} \mathrm{Cr}_{2} \mathrm{O}_{7}$ (in oxidation) titrated against ferrous sulphate solution was carried out and converted to $\mathrm{OM}$ by multiplying the organic carbon values by 1.724 with designated formula.

\subsubsection{Root-length formation}

The Root-length $(\mathrm{cm})$ and level of formation of the remediation species was determined by means of meter rule placed at the base of the primary (tap) roots from where reading took place to the apex (tip) and data recorded in $\mathrm{cm}$.

\subsubsection{Infiltration rate}

Using a double ring glass infiltrometer ( $1.17 \mathrm{~mm}$ inside ring and $3 \mathrm{~mm}$ outer ring diameter), $54.5 \mathrm{~cm}$ height and a stop watch (Bouwere, 1986), a comparative assessment of the water infiltration rate was carried out in three phases at the control and polluted microsites in pre-pollution, post-pollution and post-phytoapplication periods, The exercise was carried out for five consecutive periods at 2 months interval within ten months of postphytoapplication ecological observation. At each of the microsite replicates the infiltrometer was carefully driven (to achieve minimum or no disturbance to the soil) vertically down at a depth of $5 \mathrm{~cm}$ into the soil and $50 \mathrm{ml}(60$ $\mathrm{cm}^{3}$ ) tap water poured into it. Observing the duration of each test run for water movement, the time taken for the 
water to infiltrate into the soil in relation to repellency was recorded with the infiltration values calculated by reading the change in water level $(\mathrm{cm})$ over time $(\mathrm{min})$ from the stop watch recorder.

\subsubsection{Phytoremediation potency of the plant species:}

The potential of these species for remediation activities was assessed using classical indices among others which include: soil hydrocarbon removal index, species efficiency index, and bioaccumulation quotient index.

The amount of hydrocarbon removed or loss from the soil per plant was estimated using the Raghuvanshi et al. (2004) method using the formular:

$$
Q H=\frac{C i-C e}{M}
$$

Where $\mathrm{QH}$ is the amount of hydrocarbon removed from the soil $(\mathrm{mg} / \mathrm{g}) . C i$ is the initial concentration of hydrocarbon in the soil $(\mathrm{mg} / \mathrm{g}), C e$ is equilibrium concentration of hydrocarbon in the soil $(\mathrm{mg} / \mathrm{g})$ and $M$ is the number of plants.

The efficiency of hydrocarbon removal per plant from the soil was estimated as adopted by Badmus et al. (2007) using the equation:

$$
\mathrm{E}=\frac{(C i-C e)}{C i} \times 100
$$

Where $\mathrm{E}$ is the efficiency of species for hydrocarbon removal from the soil (\%). $\mathrm{Ci}$ is the initial concentration of hydrocarbon in the soil $(\mathrm{mg} / \mathrm{g}), C e$ is equilibrium concentration of hydrocarbon in the soil $(\mathrm{mg} / \mathrm{g})$.

The bioaccumulation quotient expresses the possibility of contaminant being significantly accumulated in plant parts, and imminent risk of health hazard. It was expressed by the formula designate:

Concentration of residual pollutant in species treated soil

\subsection{Analyses of experimental data}

The remediation performance was estimated using the Statistical Analysis System (SAS) PROC. NLIN procedure (SAS, 2002). Data were then analysed as a double-split plot design with 5 replicates using the Analysis of Variance (PROC ANOVA) procedures (SAS, 2002). Where significant differences were observed, means were separated according to the procedures of the Duncan's New Multiple Range Test (DNMRT) using least significant difference (LSD) tests at $5 \%$ probability level. Correlation analyses were used to identify the relations between the different parameters.

\section{Result}

The result has revealed the time rate or degree of infiltration per minute in the soil of pre-pollution, post-pollution and post-phytoapplication phases of ecological study. The pre-pollution soil has significantly $(p<0.05)$ low time rate of $5.00 \pm 1.00^{\mathrm{de}}$ with increased infiltration which decreased with significant difference $(p<0.05)$ of increased time rate of $7.60 \pm 2.25^{\mathrm{bc}}, 10.05 \pm 2.78^{\mathrm{ab}}$ and $12.40 \pm 2.83^{\mathrm{a}}$ across the respective low, medium and high pollution levels. The post-phytoapplication remediated waste oil soil had recorded increased infiltration among species treated soils with significantly different $(p<0.05)$ reduced time rate lower than post-pollution. The Peltophorum pterocarpum treated soil recorded an average infiltration time rate of $1.07 \pm 0.31^{\mathrm{h}}, 1.51 \pm 0.02^{\mathrm{gh}}, 2.48 \pm 0.35^{\mathrm{efdh}}$ and $3.13 \pm 1.45^{\text {defgh }}$ at the respective control, low, medium and high pollution levels. The soil under Leucaena leucocephala treatment had infiltration time rate of $1.09 \pm 0.37^{\mathrm{gh}}, 1.58 \pm 1.05^{\mathrm{fgh}}, 4.34 \pm 1.60^{\mathrm{defg}}$ and $5.82 \pm 1.95^{\mathrm{cd}}$ while Crotolaria retusa treated soil recorded an average rate of $1.60 \pm 0.09^{\text {fgh }}, 1.63 \pm 0.03^{\text {fgh }}, 3.03 \pm 1.19^{\text {defgh }}$ and $4.60 \pm 1.79^{\text {def }}$ across post-polluted species treated levels. Generally, the result has indicated enhanced infiltration rate and lesser time among species waste oil soil with $P$. pterocarpum soil having the least time rate in the order $P p<C l<L l$ of the ecological study.

\section{Discussion}

Several factors are known to influence the edaphic dynamic and functions of a given soil type in light of hydrological movement around the environment of automobile workshops. Such influencing factors include among others; the nature of soil layer, soil moisture content, rainfall intensity, temperature (Eze et al, 2011); soil texture, structure, particle density (PD), bulk density (BD), porosity, total hydrocarbon content (THC) and organic matter (OM) content (Edwin-Wosu and Nkang, 2017a). These physico-edaphic factors are increasingly exposed to alteration and changes due to anthropogenic sources that could generate large amount of waste oil as often experienced in automobile workshop environment.

The impact of pollution across various levels of incident had direct relationship with vertical hydrological process in light of infiltration process as exemplified in a positive correlation $(\mathrm{r}=0.52 ; p<0.05)$ between THC and infiltration rate and corresponding edaphic factors (Table 1).

The increase in time rate of decreased infiltration process across pollution levels was significantly higher than 
pre-pollution time rate. This could be attributed to the increased particle size of sandy component of the sandy loam soil as exemplified in a negative correlation $(\mathrm{r}=-0.42 ; p<0.05)$ between THC and sand component. The reduction in size of silt and clay exemplified in a positive correlation $(\mathrm{r}=0.23 ; p<0.05)$ between THC and silt and $(\mathrm{r}=0.30 ; p<0.05)$ for clay particles due to enhanced distortion of structural aggregates by solvent and hydrophobic component of waste oil could also be implicated in the infiltration rate decrease.

The influence of soil structure on infiltration rate in light of sand, silt and clay component (Tables, $1 \& 2$ ) due to waste oil effect has direct relationship as exemplified in a negative correlation $(\mathrm{r}=-0.50 ; p<0.05)$ between infiltration and sand indicating increased infiltration at decreased time rate and also a positive correlation $(\mathrm{r}=0.09$; $p<0.05)$ for silt and $(\mathrm{r}=0.05 ; p<0.05)$ for clay, thus reaffirming the distortion of these aggregated component and consequent decreased infiltration at increased time rate. This corroborates similar assertions by Ezeaku and Egemba, (2014), Jerzy et al. (2015) and Edwin-Wosu and Nkang, (2017a).

The significant $(p<0.05)$ decrease in particle density as represented by a negative correlation $(\mathrm{r}=-0.24$; $p<0.05)$ depicting impact on the soil component has also shown direct relationship with infiltration rate as exemplified in a negative correlation $(\mathrm{r}=-0.50 ; p<0.05)$ between infiltration and PD. This could be reaffirmed by the positive correlation $(\mathrm{r}=0.23 ; p<0.05)$ between THC and silt, and $(\mathrm{r}=0.30 ; p<0.05)$ for THC and clay and a negative correlation $(\mathrm{r}=-0.40 ; p<0.05)$ between PD and clay. This corroborates Essien and John (2010); Townsend et al. (2013) and Edwin-Wosu and Nkang (2017a).

The post pollution relationship between the bulk density and porosity has shown a corresponding direct impact on infiltration. The increased bulk density and decreased porosity across pollution levels is a function of the waste oil filling the micro and macro pore spaces, aggravated by the hydrophobic portion, base water sediment and viscosity thereby causing more compaction and adhesion among soil aggregates. This according to similar assertion by Nwite et al. (2012), Anna et al. (2015), Nwite and Alu (2015) and Edwin-Wosu and Nkang (2017a) could be represented in a positive correlation $(\mathrm{r}=0.06 ; p<0.05)$ between THC and BD and a corresponding impact exemplified in the positive correlation $(\mathrm{r}=0.21 ; p<0.05)$ between infiltration and BD.

There was increase in organic matter content of the soil across pollution levels significantly different from the pre-pollution soil habitat. Also as earlier affirmed in Edwin-Wosu and Nkang (2017a) organic matter with its colloidal nature has the potential to bind with hydrocarbon molecules as exemplified in the positive correlation ( $\mathrm{r}$ $=0.40 ; p<0.05)$ with THC thus increasing it content. The corresponding impact of organic matter in its colloidal nature on infiltration rate could be the effect of direct sorption forces between the clayey textured soil and organic matter content as exemplified in the positive correlation $(\mathrm{r}=0.19 ; p<0.05)$ between clay and OM. There was a strong adsorption of hydrocarbon molecules as exemplified in the positive correlation $(\mathrm{r}=0.30 ; p<0.05)$ between THC and clay and $(\mathrm{r}=0.40 ; p<0.05)$ between THC and OM. This might have also caused increase in the colloidal property of the soil and with the high negative charges of clay (Osman, 2013) resulting to greater compaction and dense bulk density as exemplified in a positive correlation $(\mathrm{r}=0.30 ; p<0.05)$ between $\mathrm{BD}$ and clay.

The negative correlation $(\mathrm{r}=-0.04 ; p<0.05)$ between $\mathrm{OM}$ and $\mathrm{BD}$ is an indication that organic matter might not be the only factor responsible for soil bulk density except in synergy with clay component of the soil. This reaffirms similar assertion by Vogelmann et al. (2012) on the hydrophobic characteristic of soil due to nature of organic compounds.

The positive correlation of clay and OM with hydrocarbon molecules and a corresponding increase in bulk density and inverse decrease in porosity across the pollution levels as observed in earlier correlations (Table 1) has also shown a corresponding relationship with the infiltration rate. This could be represented in the positive correlation $(\mathrm{r}=0.50 ; p<0.05)$ between clay and infiltration rate and $(\mathrm{r}=0.19 ; p<0.05)$ between OM and clay with the consequence impact of negative correlation $(\mathrm{r}=-0.47 ; p<0.05)$ between $\mathrm{OM}$ and infiltration, with resultant decreased infiltration at increased time rate.

The restoration evidence of the test plant on the physico-edaphic properties of the waste oil polluted soil has reaffirmed their hydrocarbon tolerance and demonstrated potential for phytotechnology application. Similar potential treatment could be envisaged for automobile workshops hence, known to be the hub of spent oil sources and discharge in the terrestrial environment among other sources of hydrocarbon pollution. The impact of the plant species has revealed improvement on particle size of sand, silt, and clay component of post-polluted soil. There was increase in particle size of sand in the post-phytoapplication phase of the study with $P$. pterocarpum treated soil recording a significantly $(p<0.05)$ higher percentage in the order $\mathrm{Pp}>\mathrm{Cr}>\mathrm{Ll}$. The silt and clay component were also restored to various grain sizes; with $L$. leucocephala treated soil having a greater percentage composition in the order $L l>P p>C r$. The improvement of particle density which was significantly restored was also higher in $P$. pterocarpum treated soil among the species in the order $P p>L l>C r$. This could be represented in the negative correlation $(\mathrm{r}=-0.50 ; p<0.05)$ between $\mathrm{PD}$ and infiltration rate; reflecting an increase in infiltration and decrease in THC as exemplified in the negative correlation $(\mathrm{r}=-0.24 ; p<0.05)$ between THC and PD. The impact of these species could corroborate the assertion that leguminous plants do improve the aggregate sizes of degraded soils due to improved changes in physico-chemical conditions (Wang et al., 2013; Udom and Nuga, 2015). This could also exemplified in the positive correlation $(\mathrm{r}=0.25 ; p<0.05)$ between $\mathrm{PD}$ and sand; and $(\mathrm{r}=0.15 ; p<0.05)$ 
between PD and silt; reaffirmed by the negative correlation $(\mathrm{r}=-0.42 ; p<0.05)$ between THC and sand and $(\mathrm{r}=$ $0.42 ; p<0.05$ ) between THC and PD (Edwin-Wosu and Nkang, 2017a).

The significant decrease in bulk density and increase in porosity due to the restoration potential of the species has shown $P$. pterocarpum treated soil with greater performance in the order $P p<C r<L l$ and $P p>C r>L l$ respectively. This was been attributed to the enhanced root development (Table 3 ) as exemplified in a positive correlation $(\mathrm{r}=0.40 ; p<0.05)$ between root and THC and $(\mathrm{r}=0.31 ; p<0.05)$ between root and OM. This has a corresponding relationship to enhanced infiltration as exemplified in the positive correlation $(\mathrm{r}=0.21 ; p<0.05)$ with BD. Growing plants have profound potential and impacts on the physical and chemical properties of soil. The presence of vegetation and growth of plants extensive rooting system that extends into the soil, penetrates micropores, disrupts some soil aggregates, creates channels for air and water penetration, enhances the development of soil structure, exposes more soil surface area, and enhance biodegradation of entrapped hydrophobic contaminants (Abdel et al., 2015).

The positive correlation $(\mathrm{r}=0.31 ; p<0.05)$ between plant root and $\mathrm{OM}$ is an indication of greater performance with enhanced reduction of OM across species treated soil in the order $P p<L l<C r$ and increase in the above ground accumulation in the order $\mathrm{Pp}>\mathrm{Cr}>\mathrm{Ll}$ (Table 3); with a corresponding enhanced infiltration represented in the negative correlation $(\mathrm{r}=-0.47 ; p<0.05)$ with OM. This corroborates the assertions by Njoku et al. (2009); EdwinWosu and Kinako, (2007); and Edwin-Wosu, (2013) on the status of organic matter mineralization in polluted soil.

The THC concentration of soils under macrophytic treatment were significantly lower than post-polluted soils which indicated that phytoremediation can enhance oil attenuation in which $P$. pterocarpum among the species had a greater performance in hydrocarbon reduction in the order $P p<C l<L l$ vis-à-vis increased bioaccumulation in the order $\mathrm{Pp}>\mathrm{Cl}>\mathrm{Ll}$. Such greater removal and reduction of THC content of the soil has a corresponding relationship to its high efficiency (Table 4) and bioaccumulation quotient (Table 5) despite the non significant reduction in the waste crusting hazard risk of sealing among the species treated soils; possibly due to leaf litter droppings as earlier stated in Edwin-Wosu and Nkang (2017b). This might have caused increase in OM content with a corresponding relationship in the positive correlation $(\mathrm{r}=0.40 ; p<0.05)$ between the OM and THC supported by the physicochemical properties of the waste oil pollutant (Table 6). A similar higher degradation and removal of petroleum hydrocarbon in vegetated soils than non vegetated bulk soil has been reported by Merki et al. (2005b), Wang et al. (2010), Wang et al. (2013), Udom and Nuga (2015) and Edwin-Wosu and Nkang, (2017a).The performance of $P$. pterocarpum could be attributed to its extensive root system, which could be represented in a positive correlation $(\mathrm{r}=0.40 ; p<0.05)$ between the plant root and THC content of the soil and also in the activities of the detoxifying enzyme of the plant (Edwin-Wosu and Nkang, 2016).

Table 1: Pearson correlation coefficient amongst parameters of phytoremediation waste oil polluted soil.

\begin{tabular}{|c|c|c|c|c|c|c|c|c|}
\hline Parameter & Sand & Silt & Clay & PD & BD & $\mathrm{HC}$ & THC & OM \\
\hline Sand & 1.00 & & & & & & & \\
\hline Silt & $-0.47^{\mathrm{NS}}$ & 1.00 & & & & & & \\
\hline Clay & $-0.77^{\mathrm{NS}}$ & $-0.15^{\mathrm{NS}}$ & 1.00 & & & & & \\
\hline PD & $0.25^{*}$ & $0.15^{*}$ & $-0.40^{\mathrm{NS}}$ & 1.00 & & & & \\
\hline BD & $-0.20^{\mathrm{NS}}$ & $-0.07^{\mathrm{NS}}$ & $0.30 *$ & $-0.22^{\mathrm{NS}}$ & 1.00 & & & \\
\hline Infilt. & -0.50 & $0.09^{\mathrm{NS}}$ & 0.50 & -0.50 & 0.21 & 1.00 & & \\
\hline THC & $-0.42^{\mathrm{NS}}$ & $0.23^{\mathrm{NS}}$ & $0.30 *$ & $-0.24^{*}$ & 0.06 & $0.52 *$ & 1.00 & \\
\hline \multirow[t]{2}{*}{ OM } & $-0.15^{\mathrm{NS}}$ & $-0.04^{\mathrm{NS}}$ & $0.19 *$ & $-0.62^{\mathrm{NS}}$ & $-0.04^{\mathrm{NS}}$ & -0.47 & $0.40 *$ & 1.00 \\
\hline & Root & $\mathbf{O M}$ & THC & & & & & \\
\hline Root & 1.00 & & & & & & & \\
\hline OM & 0.31 & 1.00 & & & & & & \\
\hline ТНC & 0.40 & 0.36 & 1.00 & & & & & \\
\hline
\end{tabular}


Table 2: The influence of post-phytoapplication remediation process on the physico-edaphic parameters of waste oil polluted soil habitat.

\begin{tabular}{|c|c|c|c|c|c|c|c|c|c|c|c|c|c|c|c|c|c|c|}
\hline \multirow[t]{3}{*}{ Parameter } & \multirow{3}{*}{$\begin{array}{c}\text { Pre } \\
\text { pollution }\end{array}$} & \multirow{2}{*}{\multicolumn{3}{|c|}{ Post-pollution soil }} & \multirow{2}{*}{\multicolumn{3}{|c|}{ Species controlled soil }} & \multicolumn{9}{|c|}{ Post - phytoapplication / pollution levels } & \multirow[t]{3}{*}{ Mean } & \multirow{3}{*}{$\begin{array}{c}L S D \\
(p<0.05)\end{array}$} \\
\hline & & & & & & & & \multirow{2}{*}{$\begin{array}{r}P . \\
75 \mathrm{mil}\end{array}$} & \multicolumn{2}{|c|}{ oterocarpum soil } & \multicolumn{3}{|c|}{ L. leucocephala soil } & \multicolumn{3}{|c|}{ C. retusa soil } & & \\
\hline & & $75 \mathrm{mil}$ & $150 \mathrm{ml}$ & $300 \mathrm{ml}$ & $P_{p . \text { cont }}$ & $L l$ cont & Cr. cont & & $150 \mathrm{ml}$ & $300 \mathrm{ml}$ & $75 \mathrm{ml}$ & $150 \mathrm{ml}$ & $300 \mathrm{ml}$ & $75 \mathrm{ml}$ & $150 \mathrm{ml}$ & $300 \mathrm{ml}$ & & \\
\hline \multirow[t]{3}{*}{ Sand } & 79.20 & 82.40 & 80.40 & 82.00 & 88.00 & 85.80 & 88.20 & 87.80 & 88.60 & 89.60 & 88.00 & 85.20 & 81.20 & 85.00 & 84.60 & 89.00 & 85.31 & 2.85 \\
\hline & \pm & \pm & \pm & \pm & \pm & \pm & \pm & \pm & \pm & \pm & \pm & \pm & \pm & \pm & \pm & \pm & & \\
\hline & $2.49^{\mathrm{h}}$ & $2.19^{\text {ofg }}$ & $3.36 \mathrm{~g}^{\mathrm{h}}$ & $1.73^{\mathrm{fgh}}$ & $0.71^{\mathrm{sbc}}$ & $1.10^{\mathrm{bcd}}$ & $0.84^{\mathrm{abc}}$ & $1.48^{\mathrm{abc}}$ & $2.30^{\mathrm{ab}}$ & $0.55^{a}$ & $0.00^{\mathrm{abc}}$ & $1.92^{\mathrm{cde}}$ & $2.39 \mathrm{gt}^{\mathrm{b}}$ & $0.71^{\text {cdef }}$ & $5.55^{\text {def }}$ & $0.00^{\mathrm{ab}}$ & & \\
\hline \multirow[t]{3}{*}{ Silt } & 7.60 & 6.60 & 8.20 & 6.80 & 6.20 & 10.00 & 8.00 & 8.20 & 6.00 & 6.40 & 8.00 & 10.40 & 11.00 & 9.00 & 9.40 & 8.20 & 8.13 & 2.26 \\
\hline & \pm & \pm & \pm & \pm & \pm & \pm & \pm & \pm & \pm & \pm & \pm & \pm & \pm & \pm & \pm & \pm & & \\
\hline & $2.97^{\text {deff }}$ & $2.07^{e f}$ & $2.49^{\text {bcclef }}$ & $1.48^{\mathrm{def} f}$ & $2.86^{f}$ & $0.71^{\text {abc }}$ & $1.23^{\text {bcdef }}$ & $0.84^{\text {bedef }}$ & $0.71^{f}$ & 0.89 ef & $0.71^{\text {bcdef }}$ & $0.89^{\mathrm{ab}}$ & $1.58^{2}$ & $0.00^{\text {sbcde }}$ & $3.36^{\mathrm{abcd}}$ & $0.84^{\text {bcdef } f}$ & & \\
\hline \multirow[t]{3}{*}{ Clay } & 13.20 & 11.80 & 11.40 & 11.40 & 5.80 & 4.60 & 4.60 & 4.00 & 5.80 & 2.80 & 4.00 & 5.20 & 8.20 & 6.40 & 6.60 & 5.00 & 6.93 & 1.66 \\
\hline & \pm & \pm & \pm & \pm & \pm & \pm & \pm & \pm & \pm & \pm & \pm & \pm & \pm & \pm & \pm & \pm & & \\
\hline & $0.84^{\circ}$ & $0.45^{\mathrm{ab}}$ & $0.89^{\mathrm{b}}$ & $0.89^{\mathrm{b}}$ & $2.17^{\text {def }}$ & $1.82^{2 \mathrm{efg}}$ & $1.82^{\text {efg }}$ & $0.71^{\text {fe }}$ & $1.48^{\mathrm{def}}$ & $0.45^{\mathrm{a}}$ & $0.71^{18}$ & $1.30^{\text {deff }}$ & $0.84^{\mathrm{c}}$ & $0.89^{\mathrm{de}}$ & $2.30^{\mathrm{cd}}$ & $0.71^{\text {def }}$ & & \\
\hline \multirow[t]{3}{*}{ PD } & 2.61 & 2.49 & 2.49 & 2.48 & 2.62 & 2.62 & 2.61 & 2.66 & 2.58 & 2.59 & 2.59 & 2.57 & 2.54 & 2.60 & 2.56 & 2.53 & 2.57 & 0.04 \\
\hline & \pm & \pm & \pm & \pm & \pm & \pm & \pm & \pm & \pm & \pm & \pm & \pm & \pm & \pm & \pm & \pm & & \\
\hline & $0.03^{\mathrm{bc}}$ & $0.03^{f g}$ & $0.03^{\text {fg }}$ & $0.10 \mathrm{~g}$ & $0.02^{\mathrm{ab}}$ & $0.06^{\mathrm{ab}}$ & $0.01^{\mathrm{bc}}$ & $0.04^{a}$ & $0.02^{\text {bcd }}$ & $0.01^{\text {bcd }}$ & $0.00^{\mathrm{bc}}$ & $0.02^{\mathrm{ch}}$ & $0.00^{\mathrm{de}}$ & $0.01^{\mathrm{bc}}$ & $0.02^{\mathrm{cde}}$ & $0.00^{e f}$ & & \\
\hline \multirow[t]{3}{*}{ BD } & 1.10 & 1.20 & 1.20 & 1.23 & 1.09 & 1.18 & 1.25 & 0.64 & 0.81 & 1.05 & 0.86 & 1.11 & 1.12 & 0.82 & 1.04 & 1.12 & 1.07 & 0.30 \\
\hline & \pm & \pm & \pm & \pm & \pm & \pm & \pm & \pm & \pm & \pm & \pm & \pm & \pm & \pm & \pm & \pm & & \\
\hline & $0.07^{\mathrm{b}}$ & $0.07^{\mathrm{abc}}$ & $0.07^{\mathrm{zbc}}$ & $0.13^{\mathrm{ab}}$ & $0.03^{\text {abcd }}$ & $0.05^{\text {abc }}$ & $0.04^{\mathrm{ab}}$ & $0.49^{\circ}$ & $0.45 \mathrm{de}$ & $0.05^{\text {sbcd }}$ & $0.43^{\text {cde }}$ & $0.01^{\text {sbcd }}$ & $0.02^{\mathrm{abcd}}$ & $0.46^{\mathrm{de}}$ & $0.06^{\text {bcd }}$ & $0.01^{\text {abcd }}$ & & \\
\hline $\begin{array}{l}\text { Porosity } \\
(\%)\end{array}$ & $46.36^{\mathrm{b}}$ & $51.81^{\mathrm{b}}$ & $51.81^{a b}$ & $50.40^{\mathrm{ab}}$ & $58.40^{\mathrm{b}}$ & $54.96^{\mathrm{ab}}$ & $52.11^{\mathrm{sb}}$ & $75.94^{\mathrm{c}}$ & $68.61^{\mathrm{c}}$ & $59.46^{\mathrm{b}}$ & $66.80^{\mathrm{b}}$ & $56.81^{\mathrm{b}}$ & $55.91^{\mathrm{b}}$ & $68.46^{\mathrm{b}}$ & $59.38^{b}$ & $55.73^{\mathrm{b}}$ & 58.34 & 10.00 \\
\hline \multirow[t]{3}{*}{ THC } & 0.00 & 3.26 & 4.08 & 4.56 & 0.00 & 0.00 & 0.00 & 1.50 & 1.75 & 2.15 & 1.09 & 2.52 & 3.18 & 1.66 & 1.72 & 2.66 & 2.17 & 0.61 \\
\hline & \pm & \pm & \pm & \pm & \pm & \pm & \pm & \pm & \pm & \pm & \pm & \pm & \pm & \pm & \pm & \pm & & \\
\hline & $0.00 \mathrm{~g}$ & $0.08^{b}$ & $0.45^{2}$ & $0.25^{2}$ & $0.00 \mathrm{~g}$ & $0.00 \mathrm{~g}$ & 0.008 & $0.21^{\text {def }}$ & $0.16^{\mathrm{de}}$ & $0.22^{\mathrm{cd}}$ & $0.47^{\text {ef }}$ & $0.68^{c}$ & $1.54^{b}$ & $0.12^{\mathrm{def}}$ & $0.14^{\text {de }}$ & $0.22^{\mathrm{bc}}$ & & \\
\hline \multirow[t]{3}{*}{ OM } & 1.46 & 2.40 & 3.40 & 3.64 & 2.08 & 1.73 & 1.64 & 2.37 & 2.58 & 3.00 & 2.49 & 2.61 & 3.74 & 2.41 & 2.72 & 3.32 & 2.60 & 0.72 \\
\hline & \pm & \pm & \pm & \pm & \pm & \pm & \pm & \pm & \pm & \pm & \pm & \pm & \pm & \pm & \pm & \pm & & \\
\hline & $0.21^{\mathrm{b}}$ & $0.34^{\text {defg }}$ & $0.65^{\mathrm{ab}}$ & $0.31^{2}$ & $0.29^{\mathrm{efgh}}$ & $0.91^{\text {tgh }}$ & $0.39 \mathrm{gh}^{\mathrm{h}}$ & $0.43^{\text {deflg }}$ & $0.35^{\mathrm{de}}$ & $0.63^{\mathrm{abcd}}$ & $0.6 \mathrm{1}^{\mathrm{def}}$ & $0.81^{\text {bcde }}$ & $0.57^{2}$ & $0.49^{\text {defe }}$ & $0.48^{\text {bde }}$ & $0.86^{\mathrm{abc}}$ & & \\
\hline
\end{tabular}

Note: $P p=$ Peltophorum pterocarpium. $L l=$ Leucaena leucocephala. $C r=$ Crotolaria retusa $.75 \mathrm{ml}(0.4 \% \mathrm{vw})=$ low pollution, $150 \mathrm{ml}(0.8 \% \mathrm{vw})=$ medium pollution, $300(1.5 \% \mathrm{vw})=$ high pollution. $*$ Means of five replicates and with the same superscript letter are not significantly different, using the Duncan's New Multiple Range Test (DNMRT).

Table 3: Post phytoapplication performance of remediation species on the waste oil polluted soil.

\begin{tabular}{|c|c|c|c|c|c|c|}
\hline \multirow{2}{*}{$\begin{array}{c}\text { Plant species } \\
\text { indices }\end{array}$} & \multirow{2}{*}{$\begin{array}{c}\text { Treatment } \\
\text { level }\end{array}$} & \multicolumn{3}{|c|}{ Species } & \multirow[t]{2}{*}{ Mean } & \multirow{2}{*}{$\begin{array}{c}\text { LSD } \\
(p<0.05)\end{array}$} \\
\hline & & $\begin{array}{l}\text { Peltophorum } \\
\text { pterocarpum }\end{array}$ & $\begin{array}{c}\text { Leucaena } \\
\text { leucocephala }\end{array}$ & $\begin{array}{c}\text { Crotolaria } \\
\text { retusa }\end{array}$ & & \\
\hline \multirow[t]{4}{*}{ Plant root $(\mathrm{cm})$} & Control & $73.20 \pm 10.04^{a}$ & $69.26 \pm 19.81^{a}$ & $34.90 \pm 2.97^{b}$ & 59.12 & 17.83 \\
\hline & Low & $109.40 \pm 2.30^{\mathrm{a}}$ & $62.88 \pm 0.27^{\mathrm{b}}$ & $36.00 \pm 1.12^{\mathrm{c}}$ & 69.38 & 2.05 \\
\hline & Medium & $81.18 \pm 6.00^{\mathrm{a}}$ & $55.00 \pm 24.00^{\mathrm{b}}$ & $32.00 \pm 0.82^{\mathrm{c}}$ & 55.93 & 19.40 \\
\hline & High & $36.58 \pm 0.81^{\mathrm{a}}$ & $30.20 \pm 3.90^{\mathrm{b}}$ & $23.00 \pm 1.12^{\mathrm{c}}$ & 29.76 & 3.29 \\
\hline \multirow[t]{4}{*}{ Plant THC (mg/g) } & Control & $0.00 \pm 0.00^{b}$ & $0.00 \pm 0.00^{b}$ & $0.00 \pm 0.00^{b}$ & 0.00 & 0.00 \\
\hline & Low & $62.26 \pm 1.90^{\mathrm{a}}$ & $60.38 \pm 0.39^{a}$ & $60.47 \pm 1.49^{a}$ & 61.04 & 1.95 \\
\hline & Medium & $61.55 \pm 2.10^{\mathrm{a}}$ & $58.03 \pm 3.91^{\mathrm{a}}$ & $59.29 \pm 1.91^{\mathrm{a}}$ & 59.62 & 3.84 \\
\hline & High & $57.04 \pm 0.64^{\mathrm{a}}$ & $57.06 \pm 2.59^{\mathrm{a}}$ & $58.73 \pm 5.34^{\mathrm{a}}$ & 57.61 & 4.75 \\
\hline \multirow[t]{4}{*}{ Plant TOM } & Control & $4.51 \pm 0.53^{a}$ & $1.94 \pm 0.75^{b}$ & $2.51 \pm 0.73^{b}$ & 2.99 & 0.93 \\
\hline & Low & $3.86 \pm 0.52^{\mathrm{a}}$ & $3.62 \pm 0.57^{\mathrm{a}}$ & $2.35 \pm 0.78^{b}$ & 3.28 & 0.87 \\
\hline & Medium & $3.06 \pm 0.20^{\mathrm{a}}$ & $2.89 \pm 0.76^{\mathrm{a}}$ & $2.97 \pm 1.20^{\mathrm{a}}$ & 2.97 & 1.14 \\
\hline & High & $1.85 \pm 0.75^{\mathrm{b}}$ & $1.75 \pm 0.41^{\mathrm{b}}$ & $2.97 \pm 0.26^{\mathrm{a}}$ & 2.19 & 0.71 \\
\hline
\end{tabular}

Note: $P p=$ Peltophorum pterocarpium. $\mathrm{Ll}=$ Leucaena leucocephala $. \mathrm{Cr}=$ Crotolaria retusa

* Means of five replicates and with the same superscript letter are not significantly different, using the Duncan's New Multiple Range Test (DNMRT).

Table 4: Hydrocarbon removal and efficiency of species in the waste oil polluted soil.

THC (mg/g) content (mean) Amount of hydrocarbon removed Efficiency of removal of remaining in species treated soils from species treated soil $(q)(\mathrm{mg} / \mathrm{g}) \quad$ hydrocarbon from species treated

\begin{tabular}{lllllllllllll} 
& \multicolumn{4}{c}{$(\mathbf{C e})$ per plant. } & \multicolumn{4}{c}{ per plant. } & \multicolumn{3}{c}{ soil per plant $(\mathbf{E} \%)$} \\
\hline $\begin{array}{l}\text { Species } \\
\begin{array}{l}\text { P. } \\
\text { pterocarpum }\end{array}\end{array}$ & 1.50 & 1.75 & 2.15 & $\mathbf{1 . 8 0}$ & 0.35 & 0.47 & 0.48 & $\mathbf{0 . 4 3}$ & 54.00 & 57.11 & 52.85 & $\mathbf{5 5 . 0 0}$ \\
$\begin{array}{l}\text { L. } \\
\text { leucocephala }\end{array}$ & 1.09 & 2.52 & 3.18 & $\mathbf{2 . 2 6}$ & 0.43 & 0.31 & 0.28 & $\mathbf{0 . 3 4}$ & 66.56 & 38.24 & 30.26 & $\mathbf{4 5 . 0 2}$ \\
$\begin{array}{l}\text { C. retusa } \\
\text { redium }\end{array}$ & 1.66 & 1.72 & 2.66 & $\mathbf{2 . 0 1}$ & 0.32 & 0.47 & 0.38 & $\mathbf{0 . 3 9}$ & 49.08 & 57.84 & 41.67 & $\mathbf{4 9 . 5 3}$
\end{tabular}




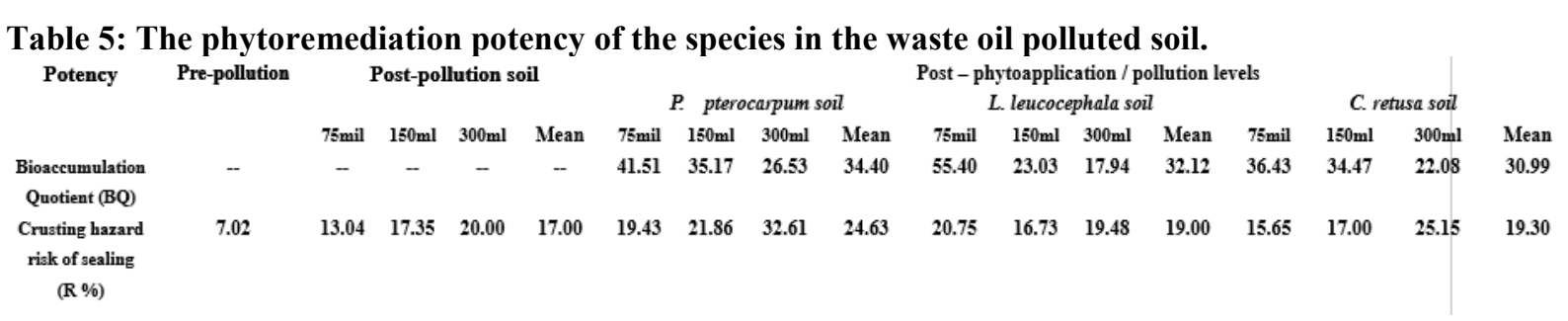

Table 6: Properties of the waste oil used for pollution of the soil

\begin{tabular}{clc}
\hline $\mathbf{S} / \mathbf{N}$ & \multicolumn{1}{c}{ Parameters } & Results \\
\hline 1 & Specific gravity & 0.89 \\
2 & Density $\left(\mathrm{g} / \mathrm{m}^{3}\right)$ & 28.00 \\
3 & $\mathrm{pH}$ & 4.03 \\
4 & Kinematics viscosity & 4.90 \\
5 & Base water sediment & 0.56 \\
\hline
\end{tabular}

\section{Conclusion}

Based on the findings it can be reemphasized that activities of automobile workshops has the potential to induce alteration on soil terrestrial habitat in terms of physico-edaphic properties of its surroundings and catchments areas. It can also be reaffirmed that the three species has demonstrated the potential as hydrocarbon tolerant and utilizing phytoremediators with a greater potential and performance attributed to the P. pterocarpum. Therefore, can be proposed for planting in automobile workshops as proactive measures and containment absorbent among other hydrocarbon restoration approach against envisaged waste oil discharge.

\section{Acknowledgments}

The authors thank colleagues and laboratory staffs that helped with fieldwork and laboratory analyses during the study. Our appreciation also goes to the blessed memory of the Late Prof. Dave Nosa Omakaro for his supervision and contributions.

\section{References}

Abdel Ghany, T. M., Mohamed, A., Al Abboud, M. E. N. \& Abdel-Rahman M. S. (2015). Rhizosphere Microorganisms as Inducers for Phytoremediation a Review. International Journal of Bioinformatics and Biomedical Engineering, 1(1), 7-15.

Adedokun, O.M. \& Ataga, A.E. (2007). Effect of Amendment and Bioaugumentation of soil polluted with crude oil Automotive Gasoline and Spent Engine oil on the growth of cowpea (Vigna unguiculata L. walp). Scientif. Res. 2(5), 1147-1149.

Adu, A. A., Aderinola, O. J. \& Kusemiju, V. (2015). Comparative Effects of Spent Engine Oil and Unused Engine Oil on the Growth and Yield of Vigna unguiculata (Cowpea). International Journal of Science and Technology, 4 (3), $105-118$.

Ajayi, O.O. (2005). Heavy metal contents of soil in automobile workshop in Lagos. Nigeria Journal of Soil Science, 15(2), 163-164.

Akindele, S. O. (1996). Basic Experimental Design in Agricultural Research, Akure, Federal Universty of Technology Akure (FUTA) Press. Pp $77-84$.

American Petroleum Institute (1980). Manual on Disposal of Petroleum Wastes. Washington DC. American Petroleum Institute.

Anna, K., Ewa, B., Jarosław, L., Agnieszka, K. \& Piotr W. (2015). Influence of Oil Contamination on Physical and Biological Properties of Forest Soil After Chainsaw Use. Water Air Soil Pollution, 226(11), 1-9. doi: $10.1007 / \mathrm{s} 11270-015-2649-2$

Anoliefo, G, O. \& Edegai, B.O. (2000). Effects of spent engine oil as contaminant on the growth of two eggplant species Solanum melongena and S. incarnum. Journal of Agriculture for fish. 1, 21 - 25.

Anoliefio, G.O. \& Vwioko, D.E. (2001). Tolerance of Chromolaena odorata (L) K.and R.grown in soul contaminated with spent lubricating oil. Journal of Tropical Bioscience, 1(1),20-24.

Ashraf, K. N. (2011). Effect of motor oil contamination on geotechnical properties of over consolidated clay. Alexandria Engineering Journal, 50,331 - 335.

ASTM (1958). Procedure for testing soils. American Soil Testing and Materials. Philadephia.

ASTM (1961). Tentative method for grain size analysis of soils. ASTM standards part 4. American Soil Testing and Materials. Philadephia. pp. 1272 - 1283.

Atlas, R.M. (1977). Stimulated Petroleum Biodegradation. Critical Rev. Microbial. 5,371-386.

Atuanya, E.I. (1987). Effect of waste engine oil pollution on physical and chemical properties of soil. A case study 
of Delta soil in Bendel State. Nigerian Journal of Applied Science, 5,155-176.

ATSDR (Agency for Toxic Substances and Disease Registry). (1997). Toxicology profile for used mineral based crankcase Oil. Department of Health and Human Services, Public Health Service Press, Atlanta, GA, USA.

Badmus, M.A.O., Audu, T.O.K. \& Anyata, B.U. (2007). Removal of lead ion from industrial waste water by activated carbon prepared from periwinkle shells. Turkish Journal of Engineering and Environmental Science, pp. $251-263$.

Baranaski, M. W. (2000). ci odkaztalcalnos cglin lodowcowych zanieczyszczanych ropopchodnym benzenem na terenie petrochmii Plock S.A. Rozpeawa doktorska, Warszawa, Wydzial Geologii, Uniwerstet Warszawski.

Blake, G.R. \& Hartge, K.H. (1986). Bulk density. In: Klute, A. (Ed.) Method of Soil Analysis, part 1. Agronomy 9. ASA, Madison. WI. P. $363-373$.

Bouwere, H. (1986). Intake rate: cylinder infiltrometer. In: Klute A. (ed.), Methods of Soil Analysis. Part 1. ASA and SSSA, Madison,WI, pp. 825-844.

Bouyoucos, G.H. (1962). Hydrometer method improved for making particle size analysis of soil. Soil Science. Agronomy Journal 53, 464 - 465.

Dauda, M. and Obi, A. M. (2000). Determination of some properties of Engine Oils Manufactured in Nigeria. Nigerian Journal of Engineering 8(2), 1-8.

Duffus, J.H. (2002). Heavy metals "a meaningless Term" (IUPAC Technical Report). Pure. Appled Chemistry, 74,793-807.

Edwin-Wosu, N.L. \& Kinako, P.D.S. (2007). Phytoremediation (series 4): carbon: nitrogen ratio as an index assessment of macrophytic remediation of a crude oil polluted terrestrial habitat. Journal of Nigerian Environmental Society, 4 (1), 95 - 99.

Edwin-Wosu, N.L. (2013). Phytoremediation (Series 5): Organic carbon, matter, phosphorus and nitrogen trajectories as indices of assessment in a macrophytic treatment of hydrocarbon degraded soil environment. European Journal of Experimental Biology, 3 (3), 11-17.

Edwin-Wosu, N. L. \& Nkang, A. (2016). Evaluation of phytoremediation potential of Peltophorum pterocarpum (DC.) Heyne Leucaena leucocephala (Lam.) De Wit. and Crotolaria retusa Linn for waste oil contaminated soils. Journal of Applied Science and Environmental Management. 20 (3), 669-678

Edwin-Wosu, N. L. \& Nkang, A. E. (2017a). Studying the Physico-edaphic and Hydraulic Conductivity of Phytoremediated Spent Oil Polluted Habitat. International Journal of Plant \& Soil Science, 17(1), 1-13.

Edwin-Wosu, N. L. \& Nkang, A. E. (2017b). The influence of phytoremediation potential on water-habitat relationship of crude oil polluted tropical Niger Delta soil: Hydraulic conductivity assessment. Nigerian Journal of Botany, 30(1), $61-80$.

Ekundayo, E.O., Aisuen, V. \& Benka, C. M.O. (1989). The effect of drilling fluids in some waste and burrow pit in western operational areas of shell petroleum Development company of Nigeria Limited on the soil and water quality of the area Environmental Consultancy Service Group, Consultancy service Unit, University of Benin, Benin City Nigeria.

Essien, O.E. \& John, I..A. (2010). Impact of Crude-Oil Spillage Pollution and Chemical Remediation on Agricultural Soil Properties and Crop Growth. Journal of Applied Science Environmental Management 14 (4), $147-154$.

Evdokimov, A.Y \& Fooks, I.G. (1989). Ecological problems of rational use of lubricating materials. Neftekhimia, Moscow. 64pp.

Eze, B. E., Devalsam, I. E. \& Oko, C. (2011). Evaluation of the Infiltration Capacity of Soils in Akpabuyo Local Government Area of Cross River, Nigeria. Journal of Geography and Geology, 3(1): 189 - 199.

Ezeaku, P.I. \& Egbemba, B.O. (2014). Yield of maize (Manoma spp.) affected by automobile oil waste and compost manure. African Journal of Biotechnology, 13 (11), 1250 - 1256.

Gradwell, M.W. (1955). The determination of specific gravities of soil as influenced by clay-mineral composition. N.Z.J. Science Technology, 37B, $283-289$.

Harry, O.B. \& Nyle, C.B. (1962). The nature of soil properties. http:/www.bnl.gov./erd/preconic/fact sheet/phytoextraction. pdf. Accessed 10 March, 2010.

Herzig, J. (2001).Wplyw zanieczyszczen organicznych nawybrane parametry fizyczne gruntow spoistych. Inzynieria Morska I, Geotechnika, 3,141-143.

Izdebska-Mucha, D. \& Jerzy T. (2008). Effect of petroleum pollution on clay soil microstructure, GEOLOGIJA 50 (Suppl.), S68-S74.

Jerzy, T., David, J.W. \& Marek, S.Z. (2015). Can hydrocarbon contamination influence clay soil grain size composition? Applied Clay Science, 109 -110, $49-54$.

Kayode, J., Oyedeji, A.A. \& Olowoyo, O. (2009). "Evaluation of the effect of pollution with spent lubricant oil on the physical and chemical properties of soil". Pacific Journal of Science Technology, 10 (1), 387-391.

Merkl, N., Schutze-Kraft, R. \& Infante, C. (2005b). Phytoremediation in the tropics - influence of heavy crude oil on root morphology characteristics of graminoids. Environ. Pollut. 138 (1), 86-91. 
Mashalah, K., Amir, H.C. \& Tajik, M. (2007). Effect of crude oil contamination on geotechnical properties of clay and sandy soil. Engineering Geology, 89 (3-4), 220-229.

Nelson, D. W. \& Sommer, L. E. (1982). Total carbon, organic carbon and organic matter. In: Page, A.C. (Ed.). Methods of Soil Analysis Part 2, $2^{\text {nd }}$ ed. Agron. Monogr. 9. ASA and SSSA. Madison, WI; pp.539-379.

Njoku, K.L., Akinola, M.O. \& Oboh, B.O. (2009). Phytoremediation of Crude Oil Contaminated Soil: The Effect Of Growth Of Glycine Max On The Physico-Chemistry and Crude Oil Contents Of Soil. Nature and Science, 7(12), 22-30.

Nwite, J.N., Mbah, C.N., Okonkwo, C.I. \& Obi, M.E. (2012). Analysis of the Physical conditions of a contaminated typic Haplustult amended with organic wastes. Int. Res. J. Agric. Sci. Soil Sci., 1(2), 058-063.

Nwite, J. N. \& Alu, M. O. (2015). Effect of different levels of spent engine oil on soil porperties, grain yield of maize and its heavy metal uptake in Abakaliki, Southeastern Nigeria. Journal of Soil Science and Environmental Management, 5(4), 44 - 51.

Odjegba, V.J \& Sadiq, A.O. (2002). Effect of Spent Oil on the growth parameters, chlorophyll and proteins levels of Amaranthus hybridus, L. The Environmentalist, 22, 23-28.

Osubor, C.C. \& Anoliefo, G.O. (2003). Inhibitory effects of spent lubricating oil on the growth and respiratory functions of Arachis hypogea L. Benin Science Digest, 1, 73-79

Osman, K. T. (2013). Forest Soils, Springer International Publishing Switzerland. Pp. 19 - 28. doi: 10.1007/9783-319-02541-4 2,

Raghuvanshi, S.P., Singh, R. \& Kaushik, C.P. (2004). Kinetic studies of Methylene blue dye bio - adsorption on Baggase. Applied Ecology and Environmental Research, 2 (2), 35-43.

Rudko, T, \& Rybczyński, R. (2010).Właściwości smarne olejów roślinnych i mineralnych stosowanych w układach tnących pilarek. Acta Agrophysica. 15(1), 145-154.

SAS Institute Inc. (2002). SAS for Windows Release 9.1, Canny, United State America, Statistical Analysis Systems Institute Incorporated.

Sharifi, M., Sadeghi, Y. \& Akbarpour, M. (2007). Germination and growth of six plant species on contaminated soil with spent oil. Inter. J. Environ., Sci. Technol., 4(4), 463-470.

Shanon, T. (2017). Phytoremediation: cleaning the soil with flowers? www. Documents/Phytoremediation\%20\%20Cleaning\%20The\%20Soil\%20With\%20Flowers.htm, accessed 28 August 2017.

Song, H. G., Wang, X. \& Bartha, R. (1990). Bioremediation potential of terrestrial fuel spills. Applied and Environmental Microbiology, 56(3), 652 - 656.

Stewarte, A.., Grimshaw, H. M. \& John, A.P. (1974). Chemical Analysis of Ecological Materials. Oxford. Blackwell Scientific Publications.

Townsend, G.T., Prince, R.C. \& Suflita, J.M. (2013). Anaerobic oxidation of crude oil hydrocarbons by the esident microorganisms of a contaminated anoxic aquifer. Environmental Science \& Technology, 37(22), 5213-5218. doi: $10.1021 / \mathrm{es} 0264495$

Udom, B.E., Mbagwu, J.S.C. \& Willie, E.S. (2008). Physical properties and maize production in a spent oilcontaminated soil bioremediated with legumes and organic nutrients. Journal of Tropical Agriculture, Food, Environment and Extension. 7 (1), 33-40

Udom, B.E. \& Nuga, B.O. (2015). Biodegradation of Petroleum Hydrocarbons in a Tropical Ultisol Using Legume Plants and Organic Manure. Journal of Agricultural Science, 7(4), 174 - 182.

Vander-Watt, H.V.H. \& Claasens, A.S. (1990). Effect of surface treatment on soil crusting and infiltration. Soil Technol. 3, 241-251.

Walkley, A. \& Black, C.A. (1934). An examination of the Degtgareff method for determining soil organic matter and proposed modification of the chronic Acid titration method. Soil Science, 37, 29-38.

Wang, J., Jia, C.R., Wong, C.K. \& Wong, P.K. (2000). Characterization of polycyclic aromatic hydrocarbons created in lubricating aromatic hydrocarbons created in lubricating oil. Water, Air and Soil Pollution 120, $381-396$

Wang, Y., Feng, J., Lin, Q., Lyu, X., Wang, X. \& Wang, G. (2013). Effects of Crude Oil Contamination on Soil Physical and Chemical Properties in Momoge Wetland of China. Chinese Geographical Science, 23 (6), 708 -715. doi: 10.1007/ s11769-013-0641-6

Wyszkowski, M. \& Ziolkowska, A. (2008). Effect of Petrol and Diesel on ciontent of organic carbon and mineral components in soil. American Journal of Sustainable Agriculture. 2(1), 54-60.

Vogelmann, E.S. (2012). Soil hydro-physical changes in natural grassland of southern Brazil subjected to burning management. Soil Research, 50,465 - 472 . Available from: $<$ http://www.publish.csiro.au/paper/SR12106.htm>.Accessed, 19 December 2013. doi: 10.1071/SR12106. 